\title{
Participatory geographic information systems use in Copan Ruinas, Honduras: the development and evaluation of an environmental restoration public participatory Geographic Information System project
}

\author{
Sistema de información geográfica participatoria usado en \\ las Ruinas Copan, Honduras: desarrollo y evaluación de \\ una restauración ambiental pública del proyecto de Sistema \\ Geográfico de Información participatoria
}

\author{
James M. Johnson ${ }^{1}$ \\ Westfield State University, USA
}

\begin{abstract}
Sustainable development is the challenge of the 21 st century, and public administration will play a part in finding new ways of meeting human needs within the constraints of natural resource systems. The nature of sustainable development has led to expanded forms of governance and new partnerships among non-governmental organizations (NGOs), non-profits, and governments at all levels. This paper examines a participatory geographic information system project being developed in Copan Ruinas, Honduras and its effect on the community stakeholders. pecifically, the participatory geographic information system project will focus on the development of a geodatabase and usable maps that integrate: small-scale (less than five hectares on average) agroforestry projects, and highland habitat restoration projects. During this research, we will focus on the geographic information system project, public participation and how the project meets the standards of the International Association for Public Participation (IAP2) pillars of participation and core values.
\end{abstract}

Keywords: GIS/PGIS, Public, Participation, Copan, Honduras

1 Masters of Public Administration, Westfield State University, 577 Western Ave. Westfield, MA, jjohnson@wsc.ma.edu

Este artículo corresponde a la ponencia presentada en el 35th Conference of Latin American Geographers realizada en San José, Costa Rica del 20 al 22 de mayo del 2018. 
James M. Johnson. Sistema de información geográfica participatoria usado en las Ruinas Copan, Honduras: desarrollo y evaluación de una restauración ambiental pública del proyecto de Sistema Geográfico de Información participatoria

\begin{abstract}
Resumen
El desarrollo sostenible es uno de los grandes retos del siglo 21, y la administración pública desempañará un papel importante en la identificación de nuevas formas para sustentar las necesidades del ser humano teniendo en cuenta las limitaciones de los recursos naturales. las características del desarrollo sostenible han llevado a diferentes formas de expansiones gubernamentales a todos los niveles, incluyendo asociaciones con organizaciones no gubernamentales (ONG) y organizaciones benéficas. la presente investigación examina un proyecto participativo de sistemas de información geográfica y sus efectos en los participantes comunitarios, el cual se está desempeñando en las Ruinas de Copan, Honduras. El enfoque del proyecto está en la creación de una base de datos geoespaciales y mapas que integrarán: proyectos de agrosilvicultura a menor escala y restauración de hábitats montañosos. a través de esta investigación, nos enfocaremos en el proyecto de información de sistemas geográficos, el nivel de participación pública, y como este proyecto se alinea con las reglas y los valores fundamentales de la asociación internacional de la participación pública.
\end{abstract}

Palabras clave: GIS/PGIS, Público, Participación, Copan, Honduras

\title{
Introduction
}

Public participation has been an integral part of democracy since the foundations of a formalized democracy dating back to as early as $500 \mathrm{BCE}$ in Greece. In the most basic form, public participation is the citizen voting process. Through the years, public participation has evolved and transformed beyond voting to involve the concept of government decision making at all levels. This involved the concept of "planning for the people" as a means of bringing the needs and ideas of the public into the planning forum. The "planning for the people" concept evolved to the principle of "planning by the people" by the 1960s (Soen 1997). The switch from planning "for" to planning "by" marked a notable shift in the participation process. These processes were examined in depth by Sherry Arnstein in her classic public participation article that breaks down the varying degrees of public participation into a typology consisting of a figurative ladder of eight rungs. Each rung reveals an increasing level of public participation involvement (Arnstein 1969). Arnstein's principles can be used to aid in the evaluation of many social projects that involve the public in the developmental process.

\section{Public Participation with Geographic Information Systems}

Geographic information systems (GIS) are a system of collecting spatial representations of data that tell a story about a specific area of interest. The use of GIS is often associated with the technological forms of GIS such as computer mapping and analysis programs but it is not limited to a 
James M. Johnson. Participatory geographic information systems use in Copan Ruinas, Honduras: the development and evaluation of an environmental restoration public participatory Geographic Information System project

technology-based system. Many forms of geographic information systems have been used through the years taking on the form of maps and catalogs of spatially represented data such as an atlas. For the sake of this paper I will limit the discussion to the information technology side of GIS with the use of personal computers and associated hardware and software. Public participation with GIS could be loosely defined as using a representational public participatory model for the use of: defining, developing, evaluating, and analyzing geographic data and information through the use of GIS. Participatory GIS (PGIS), like public participation, has a broad range of potential advantages and disadvantages. Many of the advantages and disadvantages of PGIS resonate with those of public participation in general. PGIS and associated mapping dates back to the 1960s (Fagerholm 2014) and has been a growing field since that time.

\section{Advantages of Participatory Geographic Information Systems}

Several literary works establish the importance to good public participation of a bottom-up approach to planning and decisions. This bottom-up approach, where direction and ideas come from the stakeholders instead of the organizers, is one of the key benefits of participatory GIS and public participation in general. By working with the public in the planning process of a GIS system decisions about what data to collect and how to represent it are directed from the public and not to the public. Localized knowledge and community norms will be addressed with a bottom-up approach with the use of PGIS (Fagerholm 2014; Mukherjee 2015; Knapp 2003). The bottom-up approach works as an educational conduit that is bi-directional, that is, learning is happening on both sides of the process with organizers and the participating public. Both the organizers and public benefit from a greater understanding of the needs of the people and project outcomes (Dunn 2007; Elwood 2006; Fagerholm 2014; Knapp 2003). Often local knowledge can be more accurate than that of the expected "scientific" knowledge that is passed down to the public in a top-down approach.

\section{Disadvantages of Participatory Geographic Information Systems}

As with the advantages of PGIS the potential disadvantages reflect the patterns of public participation in general. The top-down flow of ideas, planning, and decisions can exist and this limits overall empowerment of 
the public (Dunn 2007; Fagerholm 2014; Mukherjee 2015). The financial costs of PGIS hardware (computer systems) and software (GIS software packages) can be a disadvantage and limiting factor to the "true" avalibility of PGIS for less affluent communities (Dunn 2007; Elwood 2006; Fagerholm 2014; Knapp 2003; Mukherjee 2015). Similarly, the cost of time associated with the participatory process from the starting stages to completion can be a significant burden on a public that has limited time to spare due to domestic and other work constraints (Elwood 2006; Fagerholm 2014). Travel to and from participatory events from remote locations can add to the time costs for remotely located participants in the PGIS process.

The question of 'who' is in the forefront of both the public participation process and PGIS. Who is represented as the public in the process? Are marginalized groups such as women, impoverished groups, persons of color, and indiginous people included in the participatory process? Who is left out is just as important as who is included in the process.

The skill set required for technologically advanced PGIS may not be represented in the participating public. Basic computer skills and familarity with the technical jargon of GIS can limit the participation factor for the public (Dunn 2007; Elwood 2006; Fagerholm 2014; Mukherjee 2015). This limitation of skills can lead to bad data, bad conclusions, incomplete knowledge, and bad decisions in the PGIS process (Elwood 2006; Fagerholm 2014; Mukherjee 2015).

Maps have the potential to cause harm. Politics can come into play with the data and implemention of public mapping. Identification of individual families and sensitive information can be made public without permission. In simple terms, geospatial informaton can be used for neferaious purposes when it is in the wrong hands (Dunn 2007; Elwood 2006; Fagerholm 2014).

PGIS shares a good deal of benefits and disadvantages with the public particpatory model. Use of PGIS requires adequate planning to limit the disadvantages while improving the process to receive the benefits of the documented advantages. Most of all organizers of PGIS must be aware of who the 'who' is and to make the process as inclusive as possible. 
James M. Johnson. Participatory geographic information systems use in Copan Ruinas, Honduras: the development and evaluation of an environmental restoration public participatory Geographic Information System project

\section{Project description}

In 2012 the Copan 2012 Experimental Botanical Station was created to initiate efforts directed at the rehabilitation of degraded land and to provide a field based educational arena for students from around the globe. In 2015 the non-profit Kakaw for Copan was created to develop a geospatial project initiative directed at habitat restoration. The primary goals for Kakaw for Copan are for the restoration of fallow degraded farmland and efforts to improve the sustainable practices of small scale farms. The geospatial component makes use of geographic information systems (GIS) to document several ecological projects within the Department of Copan using a public participatory geographic information system (PPGIS) model. The use of GIS will enable stakeholders to spatially document information allowing for analysis. For example, stakeholders will be able to collect and monitor information reflecting the use of plots of land including the agricultural use of specific tracks within a plot. Information of this nature then is shared with other members of the agroforestry coop to aid in future agroforestry decisions. Key stakeholders include (Table 1):

- $\quad$ Kakaw for Copan, a loosely organized ad hoc non-profit group that specializes in the restoration of degraded habitat within the Copan Ruinas area.

- The Coffee Cooperative "Fraternity Ecological Limited" (CAFEL) a coffee producers coop that represents small-scale (five hectares or less) agroforestry projects.

- $\quad$ Faculty and Students of the non-profit Mayatan Bi-lingual School.

- General Public.

- $\quad$ Local and national government. 
James M. Johnson. Sistema de información geográfica participatoria usado en las Ruinas Copan, Honduras: desarrollo y evaluación de una restauración ambiental pública del proyecto de Sistema Geográfico de Información participatoria

Table 1. covers the aspects of stakeholder interest.

\begin{tabular}{|l|l|l|}
\hline \multicolumn{1}{|c|}{ Stakeholder } & \multicolumn{1}{c|}{ Interest } & \multicolumn{1}{c|}{ Investment } \\
\hline Kakaw for Copan & $\begin{array}{l}\text { Overall Project Management } \\
\text { - Habitat Restoration } \\
\text { Social Equity } \\
\text { Sustainability }\end{array}$ & $\begin{array}{l}\text { Project Organization, Labor, } \\
\text { Supplies, Funding }\end{array}$ \\
\hline $\begin{array}{l}\text { Rotary Club International } \\
\text { (Copan Ruinas Affiliate) }\end{array}$ & $\begin{array}{l}\text { Community Support, Water } \\
\text { Resource Projects, Social } \\
\text { Justice }\end{array}$ & Labor, Funding \\
\hline $\begin{array}{l}\text { Coffee Cooperative } \\
\text { "Fraternity Ecological } \\
\text { Limited" (CAFEL) }\end{array}$ & $\begin{array}{l}\text { Agroforestry, Sustainable Land } \\
\text { Use, Fair Trade }\end{array}$ & $\begin{array}{l}\text { Labor, Data Collection, GPS } \\
\text { Operations, Funding, Project } \\
\text { Organization }\end{array}$ \\
\hline $\begin{array}{l}\text { Public and Private High } \\
\text { Schools }\end{array}$ & Education, Sustainability & $\begin{array}{l}\text { Labor, Data Collection, } \\
\text { Training }\end{array}$ \\
\hline $\begin{array}{l}\text { Macaw Mountain, avian } \\
\text { rehabilitation center }\end{array}$ & $\begin{array}{l}\text { Species Rehabilitation, Public } \\
\text { Education, Habitat Preservation }\end{array}$ & $\begin{array}{l}\text { Education, } \\
\text { Not engaged yet. }\end{array}$ \\
\hline General Public & $\begin{array}{l}\text { Environmental improvements } \\
\text { and habitat restoration, potential } \\
\text { tourism revenue }\end{array}$ & Not engaged yet. \\
\hline $\begin{array}{l}\text { Local and National } \\
\text { Government }\end{array}$ & $\begin{array}{l}\text { Enviromental improvements, } \\
\text { habitat restoration, potential } \\
\text { tourism revenue }\end{array}$ & Not engaged. \\
\hline
\end{tabular}

The primary stakeholders involved are the CAFEL, and Kakaw for Copan. Kakaw for Copan spearheaded the project while the CAFEL demonstrated significant interest in helping to provide support. Both the public and government are stakeholders but are not involved with the project. Both will receive the potential benefits of rehabilitated habitat, water and soil preservation, and a increase of tourism.

\section{GIS component}

Due to the export limitations and costs associated with commercially available GIS programs: all parties agreed on the selection of non-commercial, open-source software. This decision aligns with much of the current research that critiques the "true" availability of the use of GIS for non-traditional users. Elwood states, "While the financial costs of hardware, software, and data have dropped and the options for acquiring and representing spatial information are greatly expanded for the most advantaged users, at the bottom of the digital divide relatively little has changed (2006)." Elwood points out, "A central focus in critical GIS science has 
been the uneven access to GIS, digital spatial data, and the growing number of important societal process that incorporate them (2006)."

The effects of being situated in a developing county are highly visible due to the paucity of pre-existing free datasets. Due to this limitation, the majority of data will be acquired by field documentation using handheld geographic positioning system (GPS) receivers.

\section{Geographic and Demographics}

Copan Ruinas is located in western most portion of the Department of Copan, Honduras and borders Guatemala. Copan Ruinas is situated in the highlands of Honduras (Figure 1).

- $\quad$ Department of Copan, Honduras

- $\quad$ Population (2015): 382,772

- $\quad$ Area: 3,242 square kilometers

- Municipality of Copan Ruinas

- $\quad$ Population (2015): 39,486

- $\quad$ Area: 370 square kilometers

- $\quad$ Elevation: 1,306 meters above sea level. 
James M. Johnson. Sistema de información geográfica participatoria usado en las Ruinas Copan, Honduras: desarrollo y evaluación de una restauración ambiental pública del proyecto de Sistema Geográfico de Información participatoria

Figura 1. Project area located in western Honduras

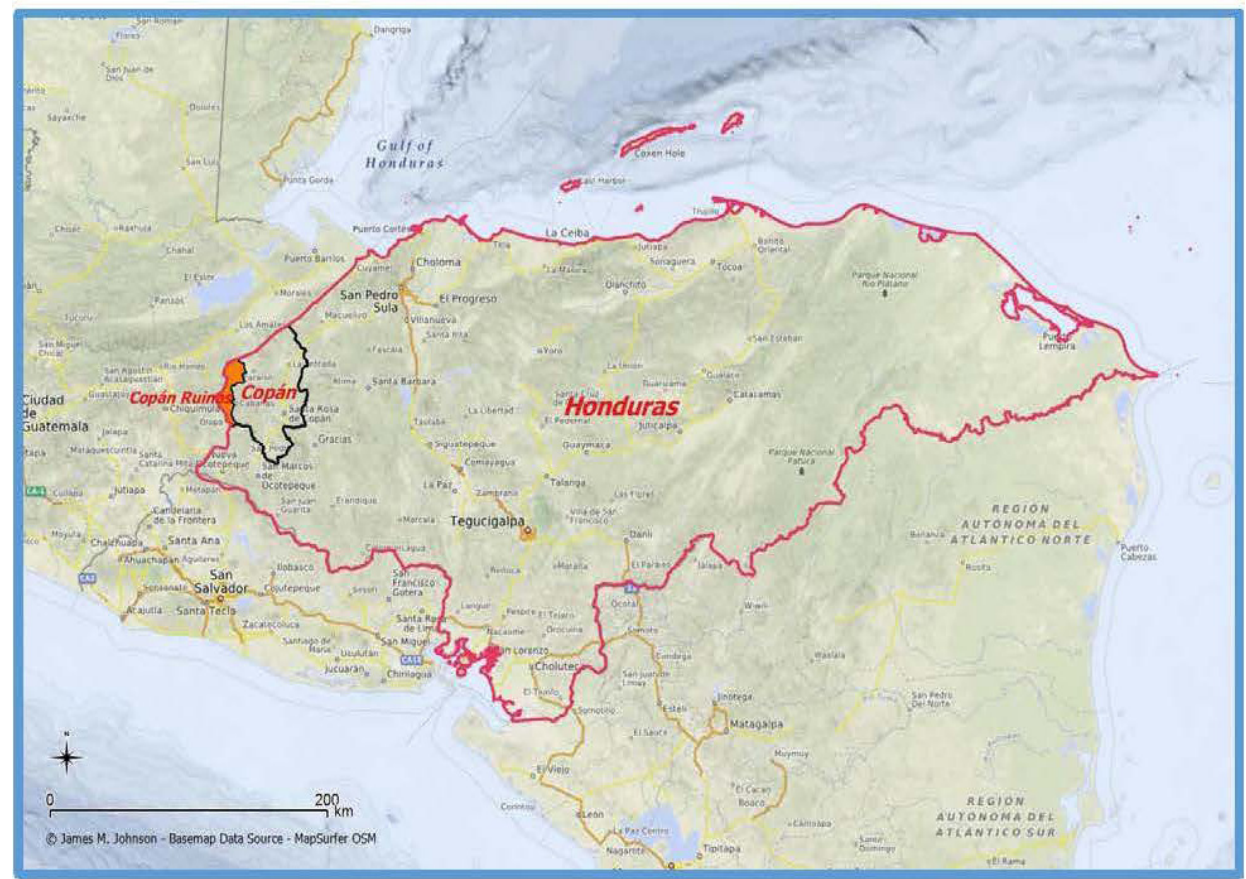

International Association for Public Participation (IAP2) three pillars

The IAP2 developed three key pillars as a foundation for the implementation and support of public participation.

"IAP2 International Associates work in industry, civil society organizations, universities, government and more. They are involved in the public participation process by supporting clients, colleagues and citizens for improved decision-making and promote best practice through the three IAP2 Pillars: Spectrum of Public Participation, Core Values, and Code of Ethics (International Association for Public Participation 2017).”

The public participation role of PPGIS for Kakaw for Copan will be evaluated using the Spectrum of Public Participation and Core Values from IAP2. 
James M. Johnson. Participatory geographic information systems use in Copan Ruinas, Honduras: the development and evaluation of an environmental restoration public participatory Geographic Information System project

\section{IAP2 Public Participation Spectrum}

To define the public role and level of involvement in the decision-making processes the IAP2 developed the Public Participation Spectrum. "The IAP2 Spectrum is quickly becoming an international standard (International Association for Public Participation 2017).” Table 2 represents the IAP2's Public Participation Spectrum. Increasing levels of public involvement are defined as we move from the left to the right side of the table with informing at the lowest level of public participation to empowerment which represents the highest level of public participation.

Table 2. IAP2's Public Participation Spectrum. Source IAP2 website

\begin{tabular}{|c|c|c|c|c|c|}
\hline & INFORM & CONSULT & INVOLVE & COLLABORATE & EMPOWER \\
\hline $\begin{array}{l}\text { Public } \\
\text { Participation } \\
\text { Goal }\end{array}$ & $\begin{array}{l}\text { To provide } \\
\text { the public } \\
\text { with balanced } \\
\text { and objective } \\
\text { information } \\
\text { to assist } \\
\text { them in } \\
\text { understanding } \\
\text { the problem, } \\
\text { alternatives, } \\
\text { opportunities } \\
\text { and/or } \\
\text { solutions. }\end{array}$ & $\begin{array}{l}\text { To obtain } \\
\text { public } \\
\text { feedback } \\
\text { on analysis, } \\
\text { alternatives } \\
\text { and/or } \\
\text { decisions. }\end{array}$ & $\begin{array}{l}\text { To work } \\
\text { directly with } \\
\text { the public } \\
\text { throughout } \\
\text { the process } \\
\text { to ensure that } \\
\text { the public } \\
\text { concerns and } \\
\text { aspirations are } \\
\text { consistently } \\
\text { understood } \\
\text { and } \\
\text { considered. }\end{array}$ & $\begin{array}{l}\text { To partner with } \\
\text { the public in each } \\
\text { aspect of the } \\
\text { decision including } \\
\text { the development of } \\
\text { alternatives and the } \\
\text { identification of the } \\
\text { preferred solution. }\end{array}$ & $\begin{array}{l}\text { To place } \\
\text { final decision } \\
\text { making } m \text { the } \\
\text { hands of the } \\
\text { public. }\end{array}$ \\
\hline $\begin{array}{l}\text { Promise to } \\
\text { the Public }\end{array}$ & $\begin{array}{l}\text { We will keep } \\
\text { the public } \\
\text { informed. }\end{array}$ & \begin{tabular}{|l|} 
We will \\
keep you \\
informed, \\
listen to and \\
acknowledge \\
concerns and \\
aspirations, \\
and provide \\
feedback \\
on how \\
public input \\
influenced \\
the decision.
\end{tabular} & $\begin{array}{l}\text { We will } \\
\text { work with } \\
\text { you to ensure } \\
\text { that your } \\
\text { concerns and } \\
\text { aspirations } \\
\text { are directly } \\
\text { reflected } \\
\text { in the } \\
\text { alternatives } \\
\text { developed } \\
\text { and provide } \\
\text { feedback on } \\
\text { how public } \\
\text { input } \\
\text { influenced } \\
\text { the decision. }\end{array}$ & $\begin{array}{l}\text { We will look to } \\
\text { you for advice } \\
\text { and innovation } \\
\mathrm{m} \text { formulating } \\
\text { solutions and } \\
\text { incorporate } \\
\text { your advice and } \\
\text { recommendations } \\
\text { into the decisions } \\
\text { to the maximum } \\
\text { extent possible. }\end{array}$ & \begin{tabular}{|l|} 
We will \\
implement \\
what you \\
decide.
\end{tabular} \\
\hline
\end{tabular}




\section{IAP2 core values}

The IAP2 created a set of core values that are designed to aid in the decision-making process for public participation activities. "These core values were developed over a two-year period with broad international input to identify those aspects of public participation which cross national, cultural, and religious boundaries. The purpose of these core values is to help make better decisions which reflect the interests and concerns of potentially affected people and entities (International Association for Public Participation 2017)."

Core values for the practice of public participation (International Association for Public Participation 2017).

1. Public participation is based on the belief that those who are affected by a decision have a right to be involved in the decision-making process.

2. Public participation includes the promise that the public's contribution will influence the decision.

3. Public participation promotes sustainable decisions by recognizing and communicating the needs and interests of all participants, including decision makers.

4. Public participation seeks out and facilitates the involvement of those potentially affected by or interested in a decision.

5. Public participation seeks input from participants in designing how they participate.

6. Public participation provides participants with the information they need to participate in a meaningful way.

7. Public participation communicates to participants how their input affected the decision. Evaluation Methodology.

For this research principal evaluation of the level of public participation was accomplished with the participant observer methodology. "Participant observation is the process of enabling researchers to learn about the activities of the people under study in the natural setting through observing and participating in those activities (Kawulich 2005).” 
James M. Johnson. Participatory geographic information systems use in Copan Ruinas, Honduras: the development and evaluation of an environmental restoration public participatory Geographic Information System project

\section{Project Evaluation}

Participant observation is a methodology that relies heavily on qualitative evaluation. Ramasubramanian tells us that qualitative evaluation has a place in social science,

"Yet, social scientists now acknowledge that a variety of qualitative methods and techniques can be used to conduct evaluations - a range of methods, including individual interviews, focus groups, place and peoplecentered behavior mapping, and the analysis of textual, graphical, and verbal narratives are part of the repertoire of evaluation researchers (2010)."

For the evaluation process a four-level rating system is used to evaluate the seven IAP2 Core Values (Table 3). The rating system consists of three ranges: low, average, and high. Each of the seven IAP2 Core Values are evaluated based on how well the current conditions are met. Ratings are assigned based on the information collected during site visits, and numerous conversations with stakeholders. 
James M. Johnson. Sistema de información geográfica participatoria usado en las Ruinas Copan, Honduras: desarrollo y evaluación de una restauración ambiental pública del proyecto de Sistema Geográfico de Información participatoria

Table 3. IAP2 Core Values Evaluation Matrix

\begin{tabular}{|c|c|c|c|}
\hline $\begin{array}{c}\text { Value } \\
\text { Number }\end{array}$ & Core Value from IAP2 & Rating & Comments/Issues \\
\hline One & $\begin{array}{l}\text { Public participation is based on the } \\
\text { belief that those who are affected by } \\
\text { a decision have a right to be involved } \\
\text { in the decision-making process. }\end{array}$ & Low & $\begin{array}{l}\text { - Little to no public input during } \\
\text { the problem definition phase. } \\
\text { - Initial project concept developed } \\
\text { by a single individual and not the } \\
\text { public. } \\
\text { - No written set of objectives or } \\
\text { goals for the project. } \\
\text { - Some stakeholders not involved. }\end{array}$ \\
\hline Two & $\begin{array}{l}\text { Public participation includes the } \\
\text { promise that the public's contribution } \\
\text { will influence the decision. }\end{array}$ & Average & $\begin{array}{l}\text { * Stakeholder input has shaped } \\
\text { elements of the project. } \\
\text { * Inputs from CAFEL incorporated } \\
\text { in project design. }\end{array}$ \\
\hline Three & $\begin{array}{l}\text { Public participation promotes } \\
\text { sustainable decisions by recognizing } \\
\text { and communicating the needs } \\
\text { and interests of all participants, } \\
\text { including decision makers. }\end{array}$ & Average & $\begin{array}{l}\text { * Students from private school } \\
\text { trained and potentially become } \\
\text { trainers. } \\
\text { - Students from public school trained } \\
\text { after input requesting inclusion of } \\
\text { public school was made. }\end{array}$ \\
\hline Four & $\begin{array}{l}\text { Public participation seeks out and } \\
\text { facilitates the involvement of those } \\
\text { potentially affected by or interested } \\
\text { in a decision. }\end{array}$ & Low & $\begin{array}{l}* \text { Diverse groups involved in the } \\
\text { process. } \\
* \text { Lack of informed consent from } \\
\text { farmers with respect to data } \\
\text { collection and mapping. } \\
\end{array}$ \\
\hline Five & $\begin{array}{l}\text { Public participation seeks input from } \\
\text { participants in designing how they } \\
\text { participate. }\end{array}$ & Low & $\begin{array}{l}\text { * No discussion or formal decision } \\
\text { about how public participation } \\
\text { will take place. } \\
\text { - Project was not initially designed } \\
\text { with public participation as a goal. }\end{array}$ \\
\hline Six & $\begin{array}{l}\text { Public participation provides } \\
\text { participants with the information } \\
\text { they need to participate in a } \\
\text { meaningful way. }\end{array}$ & Low & $\begin{array}{l}\text { * No discussion or formal decision } \\
\text { about how public participation } \\
\text { will take place. } \\
\text { * Project was not initially designed } \\
\text { with public participation as a goal. } \\
\text { * Some information provided } \\
\text { through GIS and GPS training. }\end{array}$ \\
\hline Seven & $\begin{array}{l}\text { Public participation communicates } \\
\text { to participants how their input } \\
\text { affected the decision. }\end{array}$ & $\mathrm{N} / \mathrm{A}$ & $\begin{array}{l}\text { - Project has not reached this stage } \\
\text { so no way to evaluate. }\end{array}$ \\
\hline
\end{tabular}

The Kakaw project has passed through the problem definition phase to data collection and project methods testing phase. The next phase, not yet reached, is design implementation which will require a greater input 
from the stakeholders. Evaluating at this point in time is "formative," meaning it can be used to improve the public participation elements of the remaining parts of the project (Abelson and Gauvin 2006). Overall, the project is now at the "Involve" portion of the IAP2 spectrum, having pulled in stakeholders to get their input on the gathering of base data.

\section{Value one}

Value one is rated as low due to the fact that the CAFEL became involved after the start of program development. Currently some stakeholders are involved in the planning and methodology testing phase while the problem definition was developed by an individual stakeholder. The problem definition was then presented to additional stakeholders. Problem definition is an important step of the process, and the lack of direct input from stakeholders can lead to an inadequate or biased problem definition.

Stakeholder involvement for subsequent development has been through group meetings. The farmers were represented by leadership at the CAFEL cooperative.

\section{Value Two}

Value two is rated as average due to the influence that stakeholders and the public have over the direction of the project. All aspects of the project to date have been guided by some of the stakeholders with the exception of problem definition. Decisions about the future project direction are made in a representational format by the CAFEL for the good of represented farmers.

\section{Value Three}

Value three is rated as average due to the limitations of the representational participation for the farmers. The CAFEL employees serve as the farmers' representatives, and this has prohibited a one on one exchange of ideas with the farmers. The interests of the farmers and other stakeholder groups are fully represented at these meetings and their ideas with respect to the project direction and continuation have been adopted.

Project sustainability is expressed through the training of students in basic GIS, and GPS use. Trained students potentially can run workshops in a "train the trainer" model. Student suggestions about GPS use and techniques were implemented into the project for use moving forward. 
James M. Johnson. Sistema de información geográfica participatoria usado en las Ruinas Copan, Honduras: desarrollo y evaluación de una restauración ambiental pública del proyecto de Sistema Geográfico de Información participatoria

\section{Value Four}

Value four is rated as low. The political influence of the project developer brought a broad range of "movers and shakers" to the project. However, the farmers themselves have little to no knowledge of the project, and thus do not have the ability to make informed consent to mapping processes and decisions. The ability of farmers to opt in or out with any concept of what that would mean for them is not possible at this point due to a lack of information sharing with the farmers from project leaders. Without bringing the farmers to the table valuable insight from the farmers are lost. For example, at one meeting the idea of replacing maize, a soil depleting crop, with cacao (chocolate), a crop with high cash value was discussed. The discussion surrounded the reduction in carbon emissions due to the practice of burning the harvested maize fields. Burning of the harvested fields produces carbon and leaves the soil unprotected from erosion. The stakeholders discussed the costs to replace the maize with cacao. The idea sounds simple but the stakeholders did not consider the four to five years it takes for cacao to produce a cash crop. None of the stakeholders thought about how the farmers would be able to survive the four to five-year period without a cash crop in the field. The point may have been brought up early in the discussion process if farmers were participating in the discussion.

\section{Value Five}

Value five is rated as low due to the lack of discussions about how participation will take place. How the various stakeholders, and more general public, should be involved, is a topic that should have been considered at the initial step in defining the problem and setting goals and objectives. Not all groups need to be involved to the same degree, or at the same points in the process, but effective public participation does require thorough consideration and planning of the participation methodologies. Currently there have only been scheduled meetings with involved stakeholder groups. These meetings have been open but not advertised to the public. None of the meetings covered the methods for public participation for current project development or future operations. Public participation only came to light during the data collection and project design phase. 
James M. Johnson. Participatory geographic information systems use in Copan Ruinas, Honduras: the development and evaluation of an environmental restoration public participatory Geographic Information System project

\section{Value Six}

Value six is rated as low for the same reasoning as value five, however, training on GIS and hands on training of GPS use was accomplished. This training helps stakeholders participate in a more meaningful way - as people who understand the technology and the methods for gathering the data.

\section{Value Seven}

Value seven is rated as non-applicable due to the fact that the project is still at the developmental stage and there is little information to provide as feedback.

\section{Conclusion and Recommendations}

The Kakaw for Copan project has some noble aspirations. The overall project goal is to improve the community environmentally. As stated previously, the project is still in development and still has a great deal of room for improvement in the area of public participation. Overall the project has a very poor record of public participation. The project was not initially developed as a public participatory project and this is the main hurdle to overcome. It is important moving forward to consider formalizing a problem definition, with robust public involvement. Rather than "Inform," the project should set its sights on the "Collaborate" section of the IAP2 spectrum. Stakeholders also need to have input on how they would like to participate and what communication channels should be opened. It is recommended that an advisory committee comprised of stakeholders be created to provide guidance to the project director. Input from an advisory committee may help to visualize and address a greater number of issues including a more formal process for defining the problem and establishing goals and objectives. This will be even more critical as the project moves from the data gathering phase into designing and undertaking implementation activities. When the public is not involved in the project several of the key benefits of public participation are lost. The ability of stakeholders to share traditional localized knowledge, gain social capital, fulfill public empowerment, and assist with streamlining project implementation, are diminished without public participation. The overall project at this stage demonstrates a spanning of what Arnstein refers to as "therapy" and 
"tokenism" as the public is not involved in the decision-making process other than being informed.

Limitations and burdens to stakeholder involvement include but are not limited to: time and travel to meetings, language barriers, household responsibilities, technical barriers, and legitimate concerns about safety. Using an advisory committee to represent stakeholders for small decisions will reduce the costs to participants by reducing the number of participant events and associated travel to those events.

Gender representation can also be an issue. The CAFEL is fully represented by men. Limiting stakeholders to one gender can lead to missing out on a great deal of traditional knowledge. Table 4 summarizes the IAP2 core values, and several recommendations for moving forward with the project. 
James M. Johnson. Participatory geographic information systems use in Copan Ruinas, Honduras: the development and evaluation of an environmental restoration public participatory Geographic Information System project

Tabla 4. Recommendations

\begin{tabular}{|c|c|c|}
\hline $\begin{array}{c}\text { Value } \\
\text { Number }\end{array}$ & Core Value from IAP2 & Recommendations \\
\hline One & $\begin{array}{l}\text { Public participation is based on the } \\
\text { belief that those who are affected by a } \\
\text { decision have a right to be involved in } \\
\text { the decision-making process. }\end{array}$ & $\begin{array}{l}\text { * Work with stakeholders to create a } \\
\text { written problem definition. } \\
\text { * Work with stakeholders to create } \\
\text { written goals and objectives. } \\
\text { * Work with the current stakeholders to } \\
\text { generate a list of missing stakeholders. }\end{array}$ \\
\hline Two & $\begin{array}{l}\text { Public participation includes the promise } \\
\text { that the public's contribution will } \\
\text { influence the decision. }\end{array}$ & $\begin{array}{l}\text { - Create an advisory committee } \\
\text { comprised of stakeholders. This } \\
\text { committee should have the ability to } \\
\text { provide and receive feedback on all } \\
\text { aspects of the project. }\end{array}$ \\
\hline Three & $\begin{array}{l}\text { Public participation promotes } \\
\text { sustainable decisions by recognizing and } \\
\text { communicating the needs and interests } \\
\text { of all participants, including decision } \\
\text { makers. }\end{array}$ & $\begin{array}{l}\text { * Continue to train students and faculty } \\
\text { from both private and public schools in } \\
\text { GPS and GIS operations to potentially } \\
\text { become future trainers. }\end{array}$ \\
\hline Four & $\begin{array}{l}\text { Public participation seeks out and } \\
\text { facilitates the involvement of those } \\
\text { potentially affected by or interested in a } \\
\text { decision. }\end{array}$ & $\begin{array}{l}\text { * Expand stakeholder base. } \\
\text { * Increase training to allow for informed } \\
\text { consent from farmers with respect to } \\
\text { data collection and mapping. }\end{array}$ \\
\hline Five & $\begin{array}{l}\text { Public participation seeks input from } \\
\text { participants in designing how they } \\
\text { participate. }\end{array}$ & $\begin{array}{l}\text { - Create an advisory committee } \\
\text { comprised of stakeholders for the } \\
\text { purpose of determining methods and } \\
\text { timing of participation. } \\
\text { * Include P2 in the goals and objectives } \\
\text { of project. } \\
\end{array}$ \\
\hline Six & $\begin{array}{l}\text { Public participation provides participants } \\
\text { with the information they need to } \\
\text { participate in a meaningful way. }\end{array}$ & $\begin{array}{l}\text { * Expand the sharing of information to } \\
\text { the general public through a multi- } \\
\text { faceted communication process. }\end{array}$ \\
\hline Seven & $\begin{array}{l}\text { Public participation communicates to } \\
\text { participants how their input affected the } \\
\text { decision. }\end{array}$ & $\begin{array}{l}\text { Ensure project feedback to participants } \\
\text { via bi-directional communication } \\
\text { protocol established by participants and } \\
\text { committee. }\end{array}$ \\
\hline
\end{tabular}

In this research we have considered the role of public participation and in particular the role of participatory GIS in the Kakaw for Copan project. The project is in its infancy and has a good deal of room for improvement. Several specific recommendations are provided to help this project grow into a true participatory process. Once implemented the project has the ability to redirect itself and move forward as a public participation project representing the desires and goals of the community of Copan Honduras. 
James M. Johnson. Sistema de información geográfica participatoria usado en las Ruinas Copan, Honduras: desarrollo y evaluación de una restauración ambiental pública del proyecto de Sistema Geográfico de Información participatoria

\section{Works Cited}

Abelson, Julia, and Francois-Pierre Gauvin. Assessing the Impacts of Public Participation: Concepts, Evidence, and Policy Implications. Ottawa: Canadian Policy Research Network, 2006.

Arnstein, Sherry R. "A Ladder of Citizen Participation." The Journal of the American Institute of Planners, July 1969: 216-224.

Dunn, Christine E. "Participatory GIS - a people's GIS?" Progress in Human Geography, 2007: 616-637.

Elwood, Sarah. "Critical Issues in Participatory GIS: Deconstructions, Reconstructions, and New Research Directions." Transactions in GIS, 2006: 693-708.

Fagerholm, Nora. "Whose knowledge, whose benefit? Ethical challenges of participatory mapping." In Fieldwork in the Global South, by Jenny Lunn, 158-169. New York: Routledge, 2014.

International Association for Public Participation. IAP2 Associates Program. March 26, 2017. http://www.iap2.org/?page=A12 (accessed March 26, 2017).

International Association for Public Participation. IAP2 Core Values.

March 26, 2017. http://www.iap2.org/?page=A4 (accessed March 26, 2017).

International Association for Public Participation. IAP2's Public Participation Spectrum. March 26, 2017. http://c.ymcdn.com/sites/www. iap2.org/resource/resmgr/foundations_course/IAP2_P2_Spectrum_ FINAL.pdf (accessed March 26, 2017).

Kawulich, Barbara B. (May 2005) "Participant Observation as a Data Collection Method." Forum Qualitative Social Research 6, no.2.

Knapp, Connie L. Making Community Connections. Redlands: ESRI, 2003. Mukherjee, Falguni. "Public Participatory GIS." Geography Compass, 2015: 384-394.

Ramasubramanian, Laxmi. Geographic Information Science and Public Participation. New York, NY: Springer, 2010.

Soen, Dan. "Planning and mediation - Democratic theory and public participation in Israel." Ekistics, June 1997: 60-63. 